\title{
308. T 1 コントラストの向上 ならひに撮影時间の短宿を可能にした心拍同期撮影 Improved T1 Contrast Images with 1/2 Scan Time ECG Gating
}

\begin{tabular}{|c|c|c|c|}
\hline 長凮西病院 & 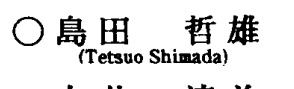 & 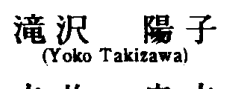 & 遠 藤eiko Endo) \\
\hline & 大佈 倩美 & 寺聿 $\underset{\text { (Tadao Térai) }}{\text { 忠 }}$ & 要 村 義孝 \\
\hline
\end{tabular}

【目的】 T1胸椎撮影時に心稢からのArtifactを削減するため、心拍同期を使用しているが、R波間隔が 長いので適切なT1Contrastが得られない。また、撮影時間も長くかかってしまう。今回我々は心拍同 期の回路に若干の変更を加え、1心拍で 2 回のData収集を行い、1/2の時間で適切なT1Contrastを持つ 画像の撮影を試みたので報告する。

【方法】今回使用した装置は以下の通りである。

東芝製

MRT 50A-III

日本光電製 LIFE SCOPE 6

自作回路

心電計からMRI装置にR波の発生を知らせる信号に

自作回路を接続し、信号から350～500msec.荤れた

時相に信号を加え、1心拍で2回のData収集を可能

にした(fig.参照)。

上記の装置を使用し以下の撮影を行った。

(1)通常の撮影と同様にTRをR-R間隔にて撮影を行った。

$\triangle T E 20$ Matrix $256 \times 256$ NEX 2 撮影時間約 8 分

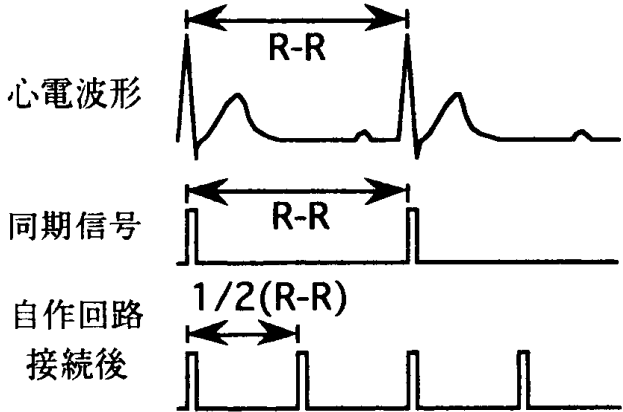

fig. 心電波形と同期信号の関係

(2)作成した回路を使用し、TRを1/2(R-R)間隔で撮影を行った。

$\triangle \mathrm{TE} 20$ Matrix $256 \times 256$ NEX 2 撮影時間約 4 分

(3)作成した回路を使用し、TRを1/2(R-R)間隔で撮影を行った。ただしFOVをDouble Matrixとし、NEX を1とした。このため異なる心拍周期のDataが交互にK-Spaceに収集されることになる。

※この時、周期的な動きが誘発するGhostの位置は下記の式で計算できる。 $\mathrm{SEP} / \mathrm{FOV}=\mathrm{TR} \times \mathrm{NEX} / \mathrm{T} \quad(\mathrm{SEP}=$ 連続する $2 つ$ つhost間のPixel数、 $\mathrm{T}=$ 運動の周期)

(3)の撮影の内容を式に代入すると

$\mathrm{SEP}=256$

となり、丁度画像に表示されない襄側に心䠞の動きによるArtifactが出現することになる。

$\triangle T E 20$ Matrix $256 \times 256$ Double NEX 1 撮影時間約 4 分

【結果】通常のTR (R-R)の撮影に比べ半分の時間で、よりT1Contrastの強い画像が撮影できた。信号 強度の点から多少 $\mathrm{S} / \mathrm{N}$ 落ちているが、C/Nが良いためそれほど気にならない。またDouble Matrix使 用時には、心埛のArtifactも画像の妻に回り、さらにECG-Gateで制御しきれなかったArtifactも通常の 倍の面皘に㹡散されるため、一番良好な画像になった。

【考察】胸椎撮影時にECG-Gateを使用しないでArtifactを抑制しょうとすると、Phase Encodeの方向 を変えたりIn FOV Saturationを使用することになるが、胸椎の沙曲のきつい人には椎体の一部にかかっ てしまう等の欠点がある。今回の発表の方法なら胸椎の湾曲にも対応できるため、どのような人にも 利用が可能である。加えてIn FOV Saturationとの併用も可能なため呼吸によるArtifactの抑制も同時に できる。使用機器の制約もあり今回ECG-Gateでの撮影を行ったがPeripheral-Gateでも利用可能である。 また撮影時間とContrastについての改善により、特に造影撮影時に効果を発揮しそうである。

【結語】近年MRIの技術の進歩はめざましく、すぐに新しい技術が発表されているが、その中で旧型 機種はその波から取り残されている感がある。Shield Gradient Coil等の内蔵されている機種が多く出 回っている現在それも仕方のないこととは思うが、まだそれ以前の機種が圧倒的多数を占める状況は もう数年続くと思われるので、今回の発表のような形で旧型機種でも利用可能な技術の開発が、現時 点での非検者の負担軽滅に最も有用だと思う。

参考文献 Michael L.Wood,R.Mark Henkelman:MR Image Artifacts from Periodic Motion.

Medical Physics,12.143-151(1985). 